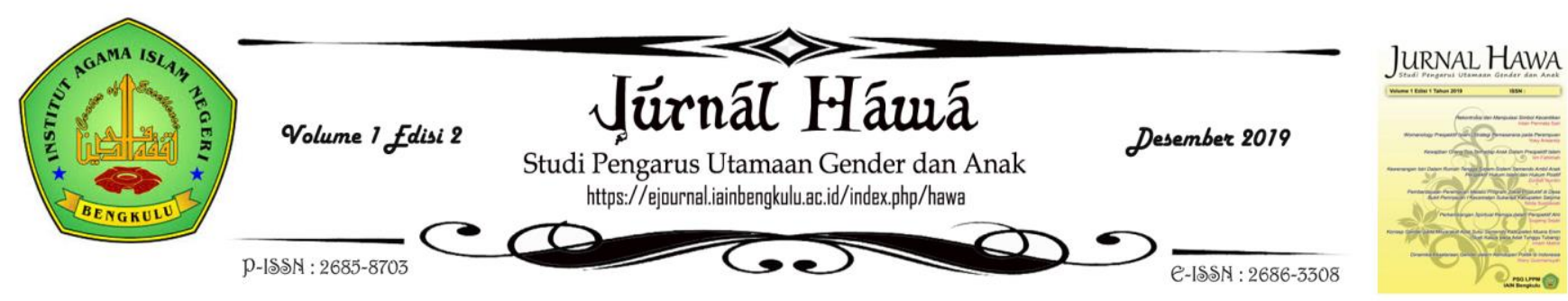

\title{
Bentuk-Bentuk Kekerasan dan Wawasan Keserasian Gender pada Ibu Rumah Tangga di Kecamatan Sungai serut Bengkulu
}

\author{
Aziza Aryati \\ Fakultas Ushuluddin Adab dan Dakwah IAIN Bengkulu \\ azizaharyati@iainbengkulu.co.id
}

\section{Info Artikel}

\author{
Diterima: Oktober \\ 2019
}

Disetujui: Oktober

2019

Dipublikasikan:

Desember 2019

\section{Keyword}

Violence, insight into harmony, and

household.

\section{Abstract}

Violence and Gender Harmony Insights in Housewives in Sungai Serut District Bengkulu. Domestic violence is an action carried out in the household by both husband, wife, and children which adversely affects physical integrity, psychological well-being, and harmony in family relationships. Women are the most vulnerable to violence in the household and in personal relationships. Violence against a wife or partner is not a new phenomenon but is a phenomenon that has lasted a long time and the degree of seriousness shows an increase over time. Violence or torture against women can be in the form of physical, psychological or sexual violence. This descriptive qualitative field research aims to describe the forms of violence received by housewives in the Sukamerindu sub-district of Sungai Serut, Bengkulu, describe the causes of violence, then describe the knowledge of housewives in the region about gender harmony and prove whether there is a link between the knowledge of gender harmony and the forms of violence they receive. In addition, this study also aims to participate in finding solutions to gender problems that exist in society. The forms of violence received by housewives in the region are economic violence, psychological violence, physical violence and sexual violence. While the causes of the abuses are: 1) the factors of the individuals concerned, 2) the factors of spouses who are having an affair, drunkards, gamblers and poor behavior, 3) economic factors with low incomes, and socio-cultural factors. Knowledge of gender harmony in this group is good but there is no link between the knowledge of gender harmony with the forms and frequency of violence received. The implication of this research is the need to provide information about gender harmony to the perpetrators of gender violence.

\section{Kata Kunei}

Kekerasan, wawasan keserasian, dan rumah tangga.

\section{Albstrak}

Bentuk-Bentuk Kekerasan dan Wawasan Keserasian Gender pada Ibu Rumah Tangga Di Kecamatan Sungai Serut Bengkulu. Kekerasan dalam rumah tangga adalah tindakan yang dilakukan di dalam rumah tangga baik oleh suami, istri, maupun anak yang berdampak buruk terhadap keutuhan fisik, psikis, dan keharmonisan hubungan keluarga. Perempuan merupakan pihak paling rentan terhadap kekerasan dalam rumah tangga maupun dalam relasi personal. Kekerasan terhadap istri atau pasangan bukan merupakan fenomena baru tetapi merupakan fenomena yang telah berlangsung lama dan derajat keseriusannya menunjukkan peningkatan sepanjang waktu. Kekerasan atau penyiksaan terhadap kaum perempuan dapat berupa kekerasan fisik, psikis, maupun kekerasan seksual. Penelitian lapangan yang berbentuk deskriptif kualitatif ini bertujuan untuk mendeskripsikan bentuk-bentuk kekerasan yang diterima oleh ibu rumah tangga di kelurahan Sukamerindu kecamatan Sungai Serut Bengkulu, mendeskripsikan faktor penyebab terjadinya kekerasan, kemudian mendeskripsikan pengetahuan ibu-rumah tangga di wilayah tersebut tentang keserasian gender serta membuktikan apakah ada keterkaitan antara pengetahuan tentang keserasian gender dengan bentuk kekerasan yang mereka terima. Di samping itu penelitian ini juga bertujuan untuk ikut mencari solusi dari persoalanpersolan gender yang ada dalam masyarakat. Bentuk-bentuk kekerasan yang diterima ibu rumah tangga di wilayah tersebut adalah kekerasan ekonomi, kekerasan psikologis, kekerasan fisik dan kekerasan seksual Sedangkan penyebab dari kekerasan-kekerasan tersebut adalah : 1) faktor dari individu yang bersangkutan, 2) faktor pasangan yang berselingkuh, pemabuk, penjudi dan berperangai buruk, 3) faktor ekonomi dengan penghasilan rendah, dan faktor sosial budaya. Pengetahuan akan keserasian gender pada kelompok ini tergolong baik tetapi tidak ada keterkaitan antara pengetahuan akan keserasian gender dengan bentuk-bentuk dan frekuensi kekerasan yang diterima. Implikasi dari penelitian ini adalah perlunya memberikan informasi tentang keserasian gender kepada pelaku kekerasan gender. 


\section{Pendahuluan}

Angka kekerasan terhadap perempuan atau kekerasan dalam rumah tangga di Provinsi Bengkulu mengalami peningkatan dari tahun ke tahun. Pada tahun 2018 terjadi 47 kasus dan pada tahun 2019 sudah terjadi 2 kasus yang mengakibatkan kematian (WCC Cahaya Perempuan Bengkulu, 2019) dan kasus yang paling memilukan adalah kasus seorang ibu yang sedang hamil tua dibunuh oleh suaminya karena cemburu, (Tribun Jakarta, 2019). Kasus tersebut terjadi di Kecamatan Sungai Serut, di mana peneliti melakukan penelitian. Menurut Artety Sumeri persoalan KDRT di masyarakat masih dianggap sebagai persoalan pribadi dan tidak dianggap sebagai persoalan tindak kekerasan yang membutuhkan dukungan lingkungan dan sosial masyarakat untuk turut melakukan pencegahan dan penanganannya. Penyebab tingginya kekerasan seksual, lanjut dia, salah satunya karena kurangnya pengetahuan dan kesadaran keluarga mengenai kesehatan seksual dan reproduksi (Yayasan WCC Cahaya Perempuan Bengkulu, 2019).

Kekerasan dalam rumah tangga adalah tindakan yang dilakukan di dalam rumah tangga baik oleh suami, istri, maupun anak yang berdampak buruk terhadap keutuhan fisik, psikis, dan keharmonisan hubungan sesuai yang termaktub dalam pasal $1 \mathrm{UU}$
Nomor 23 tahun 2004 tentang Penghapusan Kekerasan dalam Rumah Tangga (UU PKDRT). Secara faktual kekerasan terhadap perempuan menunjukkan bukti-bukti yang merefleksikan ketimpangan kekuatan sosial budaya antara laki-laki dengan perempuan. Sinclair (1999) mempertegas bahwa perempuan merupakan pihak paling rentan terhadap kekerasan dalam rumah tangga maupun dalam relasi personal. Lebih lanjut Sinclair juga menambahkan bahwa derajat keseriusan masalah kekerasan menunjukkan peningkatan sepanjang waktu, sehingga bukan tidak mungkin menimbulkan kerusakan permanen pada korban. Satu hal yang harus diingat adalah kekerasan terhadap istri atau pasangan bukan merupakan fenomena baru tetapi merupakan fenomena yang telah berlangsung lama.

Galtung (2003: 69) membagi kekerasan menjadi dua, yaitu kekerasan langsung dan kekerasan tidak langsung. Kekerasan langsung (directviolence), yaitu kekerasan yang terjadi secara fisik, yang terlihat sebagai perilaku, misalnya melukai, membunuh atau perang, sedangkan kekerasan tidak langsung (invisible), yaitu kekerasan struktural (structuralviolence). Kekerasan langsung umumnya berhubungan dengan kekerasan verbal dan fisik yang terlihat sebagai perilaku. 
Sementara dalam Gender Equality Index-Report (2013:32) diterbitkan oleh The European Institutefor Gender Equality kekerasan langsung terhadap perempuan adalah semua tindakan kekerasan yang mengakibatkan kerugian fisik, seksual, atau psikologis perempuan. Kekerasan bentuk ini dapat merugikan tubuh, pikiran, dan jiwa. Kekerasan atau penyiksaan terhadap kaum perempuan dapat berupa kekerasan fisik, psikis, maupun kekerasan seksual. Diungkapkan Fakih (2007:150) kekerasan yang bersifat fisik yaitu pemerkosaan, persetubuhan antar anggota keluarga (incest), pemukulan dan penyiksaan, bahkan yang lebih sadis lagi pemotongan alat genital perempuan. Kekerasan dalam bentuk nonfisik yang sering terjadi yaitu pelecehan seksual, menyebabkan ketidaknyamanan bagi perempuan secara emosional.

Berdasarkan latar terjadinya, kekerasan terhadap perempuan dapat dibedakan menjadi dua, yaitu kekerasan yang terjadi pada arena domestik atau kekerasan dalam rumah tangga dan kekerasan pada arena publik. Pembedaan antara kedua ranah ini didasarkan atas unsur relasi sosial antara korban dan pelaku (Sugihastuti, 2007:172). Oleh karena itu, kekerasan yang dilakukan oleh pelaku yang memiliki hubungan kekerabatan atau hubungan perkawinan, meskipun dilakukan di sektor publik, di pasar misalnya, kekerasan tersebut dapat dikategorikan sebagai kekerasan domestik. Sebaliknya, bila kekerasan dilakukan oleh orang yang tidak memiliki hubungan kekerabatan atau perkawinan, meskipun dilakukan di dalam rumah, dikategorikan sebagai kekerasan sektor publik (Sugihastuti, 2007:172-173). Menurut Hasbianto (dalam Sugihastuti, 2007:173) bahwa, kekerasan dalam rumah tangga (selanjutnya disebut kekerasan domestik) adalah suatu bentuk penganiayaan secara fisik maupun emosional atau psikologis yang merupakan suatu cara pengontrolan terhadap pasangan dalam kehidupan rumah tangga. Meiyanti (dalam Sugihastuti, 2007:173) menjelaskan jenis-jenis kekerasan domestik terhadap perempuan sebagai berikut. Pertama, kekerasan seksual yang meliputi pemaksaan dalam melakukan hubungan seksual, pemaksaan selera seksual sendiri, dan tidak memperhatikan kepuasan pihak istri. Kedua, kekerasan fisik adalah segala macam tindakan yang mengakibatkan kekerasan fisik pada perempuan yang menjadi korbannya (Sugihastuti, 2007:173). Kekerasan fisik dilakukan dengan menggunakan anggota tubuh pelaku (tangan, kaki) atau dengan alat-alat lainnya seperti memukul, menampar, meludahi, menjambak, menendang, menyulut dengan rokok, serta melukai dengan barang atau 
senjata. Ketiga, kekerasan ekonomi seperti tidak memberikan uang belanja, dan memakai atau menghabiskan uang istri. Keempat, kekerasan emosional yang meliputi mencela, menghina, mengancam atau menakut-nakuti sebagai sarana memaksakan kehendak, serta mengisolasi istri dari dunia luar.

Laporan dari Komnas Perempuan (2002) berdasarkan identifikasi peta kekerasan di berbagai pelosok wilayah Indonesia, memaparkan bahwa bentuk-bentuk kekerasan terhadap perempuan terbagi dalam delapan jenis, yaitu sebagai berikut; kekerasan fisik, penyiksaan mental, deprivasi ekonomi, diskriminasi, serangan seksual, perbudakan seksual, intimidasi berbasis gender dan perdagangan perempuan(Komnas perempuan, $2002: 43$ ).

Berdasarkan hasil SPHPN (Survey Pengalaman Hidup perempuan) Tahun 2016 mengungkapkan terdapat 4 (empat) faktor penyebab terjadinya kekerasan fisik dan/atau seksual terhadap perempuan yang dilakukan oleh pasangan yaitu faktor individu (korban perkawinan yang tidak sah secara hukum atau sering terjadi pertengkaran dengan pasangan), faktor pasangan (pasangan yang mempunyai istri lain, pasangan yang menganggur, pasangan yang pemabuk atau kecanduan narkoba), faktor sosial budaya (keluarga yang tinggal di perkotaan, dan faktor lemahnya ekonomi keluarga (Kementrian PPPA RI, 2018).

Islam telah mendudukkan perempuan di tempat yang mulia dan setara dengan laki-laki. Pengakuan kedudukan perempuan yang mulia dalam Islam dibuktikan dengan penghapusan tradisi-tradisi yang bersifat diskriminatif terhadap mereka (Warsito, 2013 :148). Islam juga telah mengatur peran dan tugas perempuan. Dalam keluarga, seorang perempuan memiliki peran sebagai ibu rumah tangga yang bertugas merawat anak dan melayani suami(Adil, 2001 : 36). Selain peran di atas, Islam juga menjamin hak-hak perempuan. Hak-hak itu antara lain, hak untuk mendapatkan warisan (seorang anak perempuan mendapat setengah anak laki-laki) (QS,4 : 11), hak mendapat pendidikan (Bukhary, hadis ke 6880) dan hak memilih pasangan (Ahmad, hadis ke 2469). Dalam masalah pernikahan, perempuan tidak hanya mendapat kebebasan memilih pasangannya, tetapi mereka juga berhak mendapat dan menentukan mas kawin (mahar) (QS, 4 : 4).

Sebagai seorang istri, perempuan dalam Islam memiliki kewajiban yaitu melayani suami (Ahmad, hadis ke 1661), menjaga harga diri, rumah tangga, dan harta suami ketika suami tidak berada di rumah dan menjaga rahasia suami (Yunahar, 1997:78). Sedangkan hak-haknya sebagai istri Al 
Jabir Al-Jazair menyebutkan beberapa hak istri atas suami antara lain: (1) Mendapatkan nafkah.

Mendapatkan nafkah batin, yaitu berhubungan intim.(3) Suami bermalam dengan istri minimal satu kali dalam empat malam. (4) Istri berhak mendapatkan pembagian yang adil jika suami mempunyai istri lebih dari satu.(5) Seorang istri berhak mendapatkan mahar/mas kawin (Abubakar, 2009 : 734).

Penelitian fieldresearch yang berjenis deskriptif (Suharsimi, $2010: 3$ ) kualitatif (Subana, 2001:17-18) ini dilakukan di Kelurahan Sukamerindu Kecamatan Sungai Serut Kota Bengkulu dengan responden sebanyak 9 orang. Pemilihan responden berdasarkan teknik non random sampling (Newman, 2003 : 216) berdasarkan pertimbangan bahwa mereka terindikasi pernah mengalami kekerasan dalam rumah tangga. Teknik penggalian data dengan melakukan wawancara mendalam dan terstruktur, kemudian melakukan pengamatan, selanjutnya data diolah dan disimpulkan.

Analisis data dilakukan melalui beberapa tahap, antara lain: 1) Membuat definisi umum atau sementara mengenai gejala yang dipelajari; 2) Merumuskan suatu hipotesis untuk menjelaskan gejala tersebut, 3) Pelajari suatu kasus untuk melihat kecocokan antara kasus dan hipotesis; 4) Jika hipotesis tidak menjelaskan kasus, rumuskan kembali hipotesis atau definisikan kembali gejala yang dipelajari; 5) Pelajari kasus-kasus negatif untuk menolak hipotesis; 6) Lanjutkan sampai hipotesis benar-benar diterima dengan cara menguji kasus-kasus yang bervariasi (Bagong, 2006 :173).

Sedangkan tujuan penelitian ini adalah untuk mengungkapkan apakah ada keterkaitan antara pengetahuan, atau wawasan keserasian gender dalam Islam yang dimiliki ibu rumah tangga dengan kepasrahan mereka dalam menerima kekerasan yang mereka alami. Di samping itu penelitian ini ingin mengungkapkan bentuk-bentuk kekerasan apa yang sering diterima oleh ibu-ibu rumah tangga di wilayah tersebut, yang bisa jadi hasil penelitian ini merupakan gambaran dari kondisi ibu-ibu di banyak wilayah di Indonesia.

\section{Pembahasan}

Berdasarkan hasil wawancara dengan para responden dapat dipetakan bahwa bentuk-bentuk kekerasan yang diterima oleh ibu rumah tangga di wilayah tersebut adalah :

1. Kekerasan Ekonomi

Kekerasan dalam masalah ekonomi bagi perempuan yang berstatus sebagai ibu rumah tangga adalah tidak dicukupinya nafkah secara rutin untuk mencukupi kebutuhan-kebutuhan dalam rumah 
tangga. Dipaksa untuk tidak bekerja, atau penguasaan terhadap hasil kerja istri untuk kepentingan pribadi (Komnas Perempuan, 2002).

Kekerasan ekonomi yang dialami para ibu rumah tangga yang menjadi responden penelitian ini adalah berupa tidak terpenuhinya nafkah lahir yang cukup untuk memenuhi kebutuhan hidupnya dan anakanaknya. Hanya 11 persen dari responden yang merasa nafkah yang diberikan suami cukup untuk biaya hidup yaitu sebesar tiga juta sebulan dengan jumlah anggota keluarga sebanyak 4 orang. Sebesar 44,4 persen yang mendapat nafkah dari suami antara satu sampai satu setengah juta, sebetulnya uang sebesar itu tidak cukup untuk menghidupi anggota keluarga yang berjumlah 4 atau 5 anggota keluarga. Tapi para ibu rumah tangga tersebut menerima dengan lapang dada meskipun hanya diberi nafkah sekecil itu, prinsip mereka dalam mengatur keuangan rumah tangga adalah "banyak habis, sedikit cukup". Sebesar 44,4 persen responden sisanya menerima nafkah dari suami dibawah satu juta rupiah perbulan, bahkan ada yang hanya menerima nafkah sebesar 500 ribu rupiah perbulan. Karenanya para ibu ini harus mencari nafkah tambahan untuk mencukupi kebutuhan hidup keluarga dengan menjadi buruh nyuci, asisten rumah tangga, pengasuh bayi, menjadi tukang ojek, berjualan, menjadi pemulung atau menjadi tukang urut. Memang para ibu tidak dipaksa oleh suami untuk ikut mencari nafkah di luar rumah, tetapi keadaan yang memaksa mereka. Ada 44 persen yang merasa didzolimi oleh para suami, mereka mengetahui penghasilan suami jauh lebih besar dari jumlah yang diberikan oleh suami kepada mereka, tetapi mereka tidak berani protes, karena hal itu akan memperparah keadaan, oleh karena itu mereka mencari jalan keluar sendiri dengan bekerja di luar rumah.Bagi ibu rumah tangga yang ikut mencari nafkah ini, suami meminta uang pada istri adalah hal yang biasa, bahkan ada yang sampai mencuri uang istri untuk membeli rokok atau bensin.

Menurut

Kementerian Pemberdayaan Perempuan dan Perlindungan Anak Republik Indonesia, kekerasan ekonomi dapat berupa meminta pasangan untuk mencukupi segala keperluan hidupnya seperti memanfaatkan atau menguras harta pasangan. Sebanyak 1 dari 4 perempuan juga mengalami kekerasan ekonomi atau sebesar $24.5 \%$. Semakin tinggi tingkat kesejahteraan masyarakat maka tingkat kekerasan yang 
dialami perempuan semakin rendah.

2. Kekerasan emosional atau psikologis

Kekerasan emosional atau psikologis, bentuknya meliputi tindakan mengancam, memanggil dengan sebutan yang tidak pantas dan mempermalukan pasangan, menjelek-jelekan dan lainnya. Sebanyak 1 dari 5 perempuan yang sudah menikah pernah mengalami kekerasan emosional yakni sebesar 20,5\%.( Komnas perempuan, 2002). Kekerasan emosional yang meliputi mencela, menghina, mengancam atau menakut-nakuti sebagai sarana memaksakan kehendak, serta mengisolasi istri dari dunia luar (Sugihastuti, 2007:173)

Dari hasil penelitian, bentuk kekerasan emosional atau psikologis yang diterima ibu rumah tangga di wilayah yang diteliti berupa: bentakan sebesar 77,8 persen, celaan 77,8 persen, hinaan 33,3 persen, ancaman 33,3 persen, ditakut-takuti 33,3 persen dan pengusiran sebesar 11,1 persen. Segala macam bentuk kekerasan emosional ini mereka alami karena ada beberapa sebab, diantaranya ; karena adanya masalah suami di luar rumah, suami sedang mabuk cinta dengan wanita idaman lain, karena istri tidak ada di rumah pada saat suami pulang kerja, karena masakan istri yang tidak sesuai dengan selera suami, karena rumah berantakan, karena anak minta uang jajan dan karena suami dalam keadaan mabuk. Kekerasan emosional ini diterima oleh para istri hampir setiap hari sebesar 33,3 persen, hanya 22,2 persen yang tidak pernah mengalami kekerasan emosional, sedangkan sisanya 44,4 persen pernah mendapatkan kekerasan emosional tetapi dalam frekuensi sedang, tidak setiap hari.

3. Kekerasan seksual

Bentuk kekerasan lainnya yaitu kekerasan seksual seperti memeluk, mencium, meraba hingga memaksa untuk melakukan hubungan seksual dibawah ancaman. Angka kekerasan seksual dalam KDRT pada perempuan yaitu sebesar 10,6\%. (KemenPPPPA RI, 2018). Kekerasan seksual yang meliputi pemaksaan dalam melakukan hubungan seksual, pemaksaan selera seksual sendiri, dan tidak memperhatikan kepuasan pihak istri (Sugihastuti, 2007 :173).

Untuk kasus kekerasan seksual yang diterima oleh responden, hanya 33,3 persen yang dipaksa melakukan hubungan seksual. Pemaksaan ini diterima karena mereka beranggapan menuruti keinginan suami adalah kewajiban istri, sedangkan menolak ajakan suami adalah dosa. Sebanyak 44,4 persen yang dipaksa untuk 
melakukan hubungan seksual dengan model atau cara yang diinginkan oleh suami, sebagian mengikuti keinginan suami dan sebagian lain menolak. Modelmodel tersebut dipelajari dari sang suami dari film-film yang ditontonnya. Sebesar 44,4 persen istri mengaku bahwa dalam berhubungan seksual suami lebih sering tidak memperdulikan kepuasan istri. Ada yang berani protes, ada pula yang diam saja, menerima dan memahami mungkin suami sedang kecapekan, atau suami kepincut dengan perempuan lain.

4. Kekerasan fisik

Kekerasan fisik dilakukan dengan menggunakan anggota tubuh pelaku (tangan, kaki) atau dengan alat-alat lainnya seperti memukul, menampar, meludahi, menjambak, menendang, menyulut dengan rokok, serta melukai dengan barang atau senjata, mencengkram dengan keras pada tubuh pasangan, dan serangkaian tindakan fisik lainnya (Sugihastuti, 2007 :173). Sebanyak $18,3 \%$ perempuan yang sudah menikah dengan jenjang usia 15-64 tahun telah mengalami kekerasan fisik dan/atau seksual. Kekerasan fisik mendominasi kasus KDRT pada perempuan yaitu sebesar $12,3 \%$ dibandingkan kekerasan seksual sebesar 10,6\% (SPHPN, 2016).
Bentuk kekerasan fisik yang diterima oleh responden adalah berupa ditampar 44,4 persen, dilempari 33,3 persen, dipukul 11,1 persen, dan ditendang 11,1 persen. Hanya 22,2 persen mengaku perlakuan kekerasan fisik tersebut mereka terima hampir setiap hari, adapun alasan para suami melakukan hal tersebut karena cemburu, karena anak minta uang jajan dan suami tidak punya uang dan karena masakan istri yang tidak sesuai dengan selera suami.

Ada bebrapa penyebab dari kekerasan tersebut antara lain terjadi karena faktor :

1. Faktor individu perempuan

Yang dimaksud Faktor individu perempuan adalah faktor yang datang dari perempuan itu sendiri. Bisa dilihat dari bentuk pengesahan perkawinan, seperti melalui kawin siri, secara agama, adat, kontrak, atau lainnya perempuan yang menikah secara siri, kontrak, dan lainnya berpotensi 1,42 kali lebih besar mengalami kekerasan fisik dan/atau seksual dibandingkan perempuan yang menikah secara resmi diakui negara melalui catatan sipil atau KUA(Komnas Perempuan, 2002). Kesediaan perempuan untuk dinikahi secara siri menjadi penyebab kekerasan yang diterima oleh perempuan 
tersebut. Ada 11,1 persen responden yang mengakui bahwa status pernikahan mereka adalah pernikahan siri, karenanya dia tidak bisa menuntut cerai ke pengadilan.

Selain itu, faktor seringnya bertengkar dengan suami, perempuan dengan faktor ini beresiko 3,95 kali lebih tinggi mengalami kekerasan fisik dan/atau seksual, dibandingkan yang jarang bertengkar dengan suami/pasangan. Perempuan yang sering menyerang suami/pasangan terlebih dahulu juga beresiko 6 kali lebih besar mengalami kekerasan fisik dan/atau seksual dibandingkan yang tidak pernah menyerang suami/pasangan lebih dahulu (Komnas Perempuan, 2002). Salah seorang dari responden yang sering menerima kekerasan psikologis mengaku bahwa penghasilan istri lebih besar dari suami, istri sering memotivasi suami agar lebih giat bekerja untuk biaya sekolah dan masa depan anak-anak, tetapi suami tidak terima "diajari" dan justru membalas dengan kemarahan, celaan dan hinaan yang selanjutnya menyebabkan pertengkaran.

\section{Faktor pasangan}

Faktor pasangan adalah faktor yang datang dari para suami, bisa karena suami memiliki wanita; Suami pemabuk atau pecandu narkoba; Atau karena suami yang penganggur. Dari sembilan responden yang diteliti, empat orang di antara mereka mengaku bahwa suami mereka telah menikah dengan perempuan lain, baik secara siri, atau hanya tinggal serumah tanpa ikatan perkawinan atau hanya sekedar selingkuh. Dua diantara mereka menyatakan bahwa suami mereka sudah mempunyai anak dengan perempuan lain tersebut, sedangkan satu orang menyaksikan suaminya telah hidup bersama tanpa ikatan perkawinan yang sah dengan perempuan tetangganya sendiri, dan satu orang lagi menduga uang hasil suami bekerja habis untuk dinikmati bersama perempuan lain.

Perempuan yang suaminya memiliki pasangan lain beresiko 1,34 kali lebih besar mengalami kekerasan fisik dan/atau seksual dibandingkan perempuan yang suaminya tidak mempunyai istri/pasangan lain. Begitu juga dengan perempuan yang suaminya berselingkuh dengan perempuan lain cenderung mengalami kekerasan fisik dan/atau seksual 2,48 kali lebih besar dibandingkan yang tidak berselingkuh (Komnas Perempuan, 2002).

Disamping itu ada satu orang responden yang memiliki suami pemabuk, dia merasa tertekan 
secara psikologis, malu kepada para tetangga karena pulang dari bekerja suaminya sering ngomel tidak jelas, mengamuk tanpa alasan yang jelas dan dia merasa kesepian karena sang suami tidak bisa diajak sharing masalah-masalah kehidupan yang dihadapinya. Sang istri mengaku sering menangis sendirian, tetapi tidak ada yang bisa dilakukan (seperti minta cerai) karena meskipun pemabuk suaminya masih memenuhi kebutuhan keluarga dan memikirkan masa depan anak.

Ada seorang responden lagi yang mengaku suaminya seorang penjudi, sehingga kebutuhan keluarga sering tidak cukup karena penghasilan suami sebagian besar dihabiskan untuk berjudi. Karenanya istri tersebut dengan sukarela mencari pekerjaan yang bisa menghasilkan uang dengan cara mengasuh anak balita tetangga. Karena melihat istri punya penghasilan, suami malah sering minta uang kepada istri untuk membeli rokok dan bensin.

Perempuan dengan suami yang pernah minum minuman keras, cenderung 1,56 kali lebih besar mengalami kekerasan fisik dan/atau seksual dibandingkan yang suaminya tidak pernah minum miras. Begitu juga dengan perempuan yang memiliki suami suka mabuk minimal seminggu sekali, beresiko 2,25 kali lebih besar mengalami kekerasan fisik dan/atau seksual dibandingkan yang tidak pernah mabuk. Perempuan dengan suami pengguna narkotika beresiko mengalami kekerasan fisik dan/atau seksual 2 kali lebih besar dibandingkan dengan perempuan yang tidak pernah menggunakan narkotika. Perempuan yang memiliki suami pengguna narkotika tercatat 45,1\% mengalami kekerasan fisik, 35,6\% mengalami kekerasan seksual, 54,7\% mengalami kekerasan fisikdan/seksual, 59,3\% mengalami kekerasan ekonomi, 61,3\% mengalami kekerasan emosional/psikis, dan yang paling tinggi yaitu $74,8 \%$ mengalami kekerasan pembatasan aktivitas.

Selain itu ada juga responden yang mengaku suaminya pernah/sering berkelahi atau ribut dengan orang lain di terminal tempat suaminya bekerja. Faktor suami yang pernah berkelahi fisik dengan orang lain, beresiko 1,87 kali lebih besar mengalami kekerasan fisik dan/atau seksual dibandingkan yang tidak pernah berkelahi fisik.

Perempuan yang memiliki suami menggangurberesiko 1,36 kali lebih besar mengalami kekerasan fisik dan/atau seksual dibandingkan yang pasangannya bekerja/tidak menganggur. Dari 9 responden yang diteliti tidak ada yang memiliki suami penganggur, semua bekerja, meskipun dengan penghasilan yang sangat kecil, kurang dari satu juta.

\section{Faktor Ekonomi}

Dari hasil penelitian diperoleh kesimpulan bahwa faktor yang paling besar pengaruhnya terhadap kekerasan yang diterima oleh para responden adalah faktor ekonomi. Sebesar 77,8 persen dari 
responden bersuamikan buruh harian lepas yang tidak tetap penghasilannya. Kalaupun sedang ada pekerjaan mereka biasanya memperoleh penghasilan antara 50 ribu rupiah sampai 125 ribu rupiah per hari, tetapi jika sedang tidak ada pekerjaan maka tidak ada uang yang masuk. 11, 1 persen suami berprofesi sebagai satpam di pasar dengan penghasilan satu juta rupiah per bulan. Hanya satu orang saja yang suaminya bekerja di BUMN dengan gaji delapan juta perbulan, tetapi yang diserahkan kepada istri sah hanya tiga juta perbulan, sedangkan sisanya untuk suami dan istri sirinya.

Perempuan yang berasal dari rumahtangga dengan tingkat kesejahteraan yang semakin rendah cenderung memiliki risiko yang lebih tinggi untuk mengalami kekerasan fisik dan/atau seksual oleh pasangan. Perempuan yang berasal dari rumah tangga miskin memiliki risiko 1,4 kali lebih besar mengalami kekerasan fisik dan/atau seksual oleh pasangan dibandingkan kelompok kaya. Aspek ekonomi merupakan aspek yang lebih dominan menjadi faktor kekerasan pada perempuan dibandingkan dengan aspek pendidikan. Hal ini paling tidak diindikasikan oleh pekerjaan pelaku yang sebagian besar adalah buruh, di mana tingkat upah buruh di Indonesia masih tergolong rendah dan hal ini berdampak pada tingkat kesejahteraan rumah tangga (KemenPPPA, 2016)

4. Faktor sosial budaya
Termasuk faktor sosial budaya adalah keyakinan atau prinsip yang dipegang oleh perempuan yang keyakinan tersebut dibentuk oleh lingkungan atau budaya dimana mereka tinggal. Dalam penelitian ini ditemukan 88,9 persen responden berkeyakinan atau berpikir bahwa suami adalah imam keluarga, kedudukannya lebih tinggi dari istri, maka wajar saja kalau suami melakukan kekerasan terhadap istri, apalagi bila suami satu-satunya yang mencari nafkah di rumah tangga tersebut. Menurut mereka adalah wajar jika suami marah, membentak atau kekerasankekerasan psikologis lainnya untuk meluruskan atau menasehati istri.

Faktor sosial budaya yang lain, seperti timbulnya rasa khawatir akan bahaya kejahatan yang mengancam. Perempuan yang selalu dibayangi kekhawatiran ini memiliki risiko 1,68 kali lebih besar mengalami kekerasan fisik dan/atau seksual oleh pasangan, dibandingkan mereka yang tidak merasa khawatir. Perempuan yang tinggal di daerah perkotaan memiliki risiko 1,2 kali lebih besar mengalami kekerasan fisik dan/atau seksual oleh pasangan dibandingkan mereka yang tinggal di daerah perdesaan (KemenPPPA, 2016). Wilayah yang diteliti adalah perkotaan terletak di Kodia Bengkulu, lokasi sangat dekat dengan jantung kota, hanya berjarak satu kilometer dari titik nol kota.

Berdasarkan hasil penelitian dapat diuraikan bahwa dari segi 
pengetahuan atau wawasan keserasian gender diketahui wawasan responden mengenai kesetaraan gender sangat baik, sebanyak 100 persen berpendapat bahwa adalah hal yang wajar jika suami ikut membantu pekerjaan istri dalam mengurus rumah tangga, 77,7 persen berpendapat suami tidak boleh membentak, mencela atau menghina istri baik di dalam rumah maupun di depan umum. Semua responden berpendapat bahwa kewajiban mencari nafkah ada pada suami, dan istri tidak ada kewajiban mencari nafkah, jika ada istri yang ikut mencari nafkah sifatnya hanya sunnah untuk membantu suami.

Semua responden berpendapat bahwa suami tidak boleh memukul istri dalam bentuk apapun dan semua berpendapat suami tidak boleh memaksa istri untuk bekerja, hanya saja jika istri bekerja harus dengan sukarela dan uangnya boleh diminta oleh suami tetapi meminta tanpa paksaan, sebagai bentuk kasih sayang istri pada suami. Syaikh Muhammad Abu Zuh-rah mengatakan bahwa pekerjaan yang sesungguhnya bagi wanita adalah mengurus rumah tangganya. Pengaturan kerjasama antara pria dan wanita harus sejalan; pria mencari nafkah untuk penghidupan dan wanita berada di rumah untuk mengurus rumah tangga (Adil, 2001 : 25). Kalaupun perempuan memiliki kesempatan untuk berkarir di ruang publik maka perempuan harus mampu eksis secara optimal di tempat kerja maupun sebagai ibu rumah tangga.
Pada saat itu perempuan memiliki beban ganda (double burden), di satu sisi mereka perlu berusaha sendiri tetapi di sisi lain dituntut lebih konsisten untuk mengasuh anak dan mengurus keluarga (Nasarudin Umar, 2001).

Adapun pengetahuan para ibu rumah tangga tentang kekerasan seksual tergambar sebagai berikut: 66,7 persen berpendapat suami boleh memaksa istri untuk berhubungan seks kapanpun suami menginginkan dan istri harus memenuhi keinginan tersebut dengan alasan takut dosa dan sunah Rasul. Sebanyak 33,3 persen lainnya berpendapat suami tidak boleh memaksa istri, dan istri berhak menolak jika istri sedang tidak menginginkan karena alasan capek, faktor usia, atau kekesalan akibat tingkah suami. Semua responden berpendapat bahwa suami adalah imam keluarga dan kedudukannya lebih tinggi dibandingkan istri.

Hanya 11,1 persen responden menjawab bahwa suami boleh memaksa istri untuk mengikuti gaya atau model yang diinginkan suami dalam berhubungan seks dan istri harus mengikuti keinginan tersebut. Selebihnya 88,9 persen menjawab suami tidak boleh memaksa istri untuk mengikuti gaya atau model berhubungan seks tertentu kepada istri. Meskipun responden menjawab suami tidak boleh memaksa model atau gaya tertentu tetapi 
mereka mengaku menuruti jika suami menginginkan model atau gaya tertentu dengan alasan harus mengikuti suami.

\section{Kesimpulan}

Setelah melakukan penelitian, peneliti menyimpulkan bahwa bentukbentuk kekerasan yang diterima oleh ibu rumah tangga di kelurahan Sukamerindu adalah kekerasan ekonomi sebesar 88,9 persen, kekerasan psikologis sebesar 77,8 persen, kekerasan fisik 44,4 persen, dan kekerasan seksual sebesar 33,3 persen. Adapun faktor penyebab terbesar adalah faktor ekonomi sebesar 88,9 persen berpenghasilan kurang dari 1,5 juta rupiah perbulan, faktor pasangan yang berselingkuh atau punya istri lain, pasangan yang pemabuk, penjudi dan pasangan yang berwatak keras sebesar 55.6 persen. Urutan ketiga adalah faktor individu perempuan sebesar 22,2 persen dan faktor sosial budaya. Sedangkan wawasan atau pengetahuan akan kesetaraan gender di kalangan responden sangat baik, sehingga temuan peneliti adalah tidak ada keterkaitan antara wawasan kesetaraan gender atau pengetahuan ibu rumah tangga tentang keserasian gender dengan kekerasan yang mereka terima dalam rumah tangganya. Temuan lain adalah pemahaman yang salah akan doktrin agama sehingga mereka hanya pasrah pada kondisi, tidak berani protes karena takut berdosa. Hal ini mungkin memerlukan penelitian selanjutnya. Wallahua'lam.

\section{Daftar Pustaka}

Abu Bakar Jabir Jazair, Minhajul Muslim, (Surakarta: Insan Kamil, cet pertama, 2009).

Adil Fathi Abdullah, Menjadi Ibu Ideal, (Jakarta: Pustaka Al-Kautsar, cet pertama, 2001).

Al-Bukhori, Muhammad bin Ismail. Al-Jami' As-Shohih Lilbukhori, (Kairo: MaktabahSalafiah.tt).

Al-Jazair, Abu Bakar Jabir, Minhajul Muslim, diterjemahkan

Ensiklopedi Muslim, (Jakarta: Darul Falah, 2000).

Bagong Suyanto dkk, MetodePenelitianSosial, (Jakarta: Kencana, 2006)

Fakih, M. Analisis Gender danTransformasi Sosial. (Yogyakarta:Pustaka Pelajar, 2007).

Galtung, J, LocalAuthorities as Peace Factors/Actors/ Workers. Journalof World-Systems Research, 6(3), 860-872. https://doi.org/10.5195/JWS R.2000.207.

Gender Equality Index-Report. 2013. Vil-nius.

Retrievedfromhttp:/ / eige. europa.eu/sites/default/files / doc-uments/Gender-EqualityIndex-Report.pdf

https://bengkulu.antaranews.com/be rita/59562/wcc-cahaya- 
perempuan-kdrt-di-bengkulumakin-mengkhawatirkan.

https:/ /jakarta.tribunnews.com/2019 /02/25/sederet-fakta-ibu-hamildi-bengkulu-dibunuh-suamipelaku-dia-seperti-merahasiakansesuatu.

https:/ / www.kemenpppa.go.id/inde x.php/page/read/31/1742/ peremp uan-rentan-jadi-korban-kdrt-kenalifaktor-penyebabnya\#diunduh 1910-2019.

Ilyas, Yunahar,Feminisme dalam Kajian Tafsir Al-Qur'an Klasik dan Kontemporer, (Yogyakarta: Pustaka Pelajar, 1997).

Komnas Perempuan,PetaKekerasan: Pengalaman Perempuan Indonesia. Ameepro. Jakarta, 2002).

Sinclair, D. Memberdayakan PerempuanKorban Kekerasan Dalam Rumah Tangga/ Hubungan Intim. (Terjemahan: Betariani Kristi Poerwandari). Program kajian Wanita PPs. Universitas Indonesia, (1999).
Sugihastuti dan Septiawan, Gender dan Inferioritas Perempuan: Praktik Kritik Sastra Feminis, (Yogyakarta: Pustaka Pelajar, 2007).

Arikunto, Suharsimi, Prosedur Penelitian Suatu Pendekatan Praktik, (Jakarta: PT RinekaCipta, 2010).

Umar, Nasaruddin, Argumen

KesetaraanJender: Perspektif AlQur'an. (Jakarta: Penerbit Paramadina, 2001).

W.L. Newman, Social Work Research Methods, qualitative and quantitative approaches, (Boston:Pearson,2003).

Warsito, Perempuan dalam keluarga menurut Konsep Islam dan Barat, dalam jurnal Profetika, Jurnal Studi Islam, Vol. 14, No. 2, Desember 2013. 